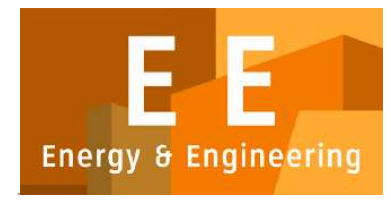

PAPER - OPEN ACCESS

\title{
Jelajah Kearifan Teknologi Bangunan Arsitektur Nusantara
}

\author{
Author $\quad:$ Ch. Koesmartadi dan D.Lindarto \\ DOI $\quad: 10.32734 /$ ee.v3i1.851 \\ Electronic ISSN $\quad: 2654-704 X$ \\ Print ISSN : $2654-7031$
}

Volume 3 Issue 1 - 2020 TALENTA Conference Series: Energy \& Engineering (EE)

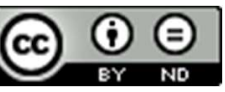

This work is licensed under a Creative Commons Attribution-NoDerivatives 4.0 International License.

Published under licence by TALENTA Publisher, Universitas Sumatera Utara

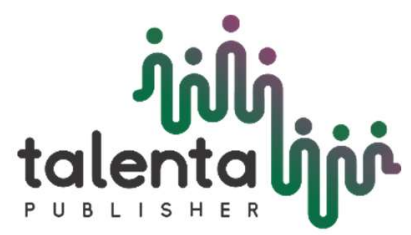




\title{
jibli (4) \\ EE Conference Series 03 (2020) \\ TALENTA Conference Series
}

$P$ P L I S HER

Available online at https://talentaconfseries.usu.ac.id/ee

\section{Jelajah Kearifan Teknologi Bangunan Arsitektur Nusantara Exploration of Wisdom Architecture Technology Building Archipelago}

\author{
Ch. Koesmartadia ${ }^{\mathrm{a}}$ D.Lindarto ${ }^{\mathrm{b}}$ \\ ${ }^{a}$ Dept.Arsitektur, Universitas Katolik Soegijapranata, Jl.Pawiyatan Luhur IV/1 Bendan Duwur, Semarang \\ ${ }^{b}$ Dept. Arsitektur, Universitas Sumatera Utara, Jalan Perpustakaan 1 Kampus USU, Medan 20211 \\ ch.koesmartadi@unika.ac.id, dwi.lindarto@usu.ac.id
}

\begin{abstract}
Abstrak
Sejauh ini pengetahuan teknologi bangunan Indonesia yang diketengahkan dalam pendidikan formal lazimnya adalah pengetahuan yang diturunkan dari pemikiran non-nusantara (notabene adalah teknologi bangunan arsitektur barat). Hal demikian memunculkan diskusi timpang (menjurus kepada beda tafsir) ketika dilakukan tindak pembahasan struktur dan konstruksi arsitektur tradisional Nusantara dengan menggunakan idiomatika teknologi bangunan tradisional Barat. Dengan focus ke-iklim-an dan ke-gempa-an yang menjadi faktor pembentuk dalam teknologi penegakkan bangunan nusantara maka tulisan ini bertujuan mengungkapkan beberapa pemikiran teknologi bangunan arsitektur nusantara yang mempunyai kebedaan dengan teknologi bangunan barat. Melalui pendekatan deskriptif eksploratif dilakukan penjelajahan dengan interpretasi normatif atas penyandingan beberapa obyek arsitektur nusantara dalam konteks teknologi bangunan nusantara. Jelajah menghasilkan temuan pengetahuan teknologi bangunan nusantara yaitu dasar pemikiran struktur konstruksi wilayah dua musim, konsekwensi ruang arsitektural nusantara, teknik konstruksi ikat dan sambungan nusantara dan keragaman titik berat serta peran konstruksi sebagai pembentuk tempat (place). Jelajah ini dimaksudkan untuk membentuk mindset pensejajaran kearifan lokal arsitektur nusantara dengan ilmu struktur konstruksi barat. Tidak ada lagi hambatan ketidak percayaan penalaran bahwa pengetahuan Arsitektur Nusantara memang nyata berbeda dengan pengetahuan Arsitektur Barat.
\end{abstract}

Kata kunci: Teknologi Bangunan, Arsitektur Nusantara, Kearifan Lokal;

\section{Abstract}

So far, the knowledge of Indonesian building technology that is presented in formal education is usually knowledge derived from nonarchipelago thinking (incidentally is the technology of western architectural building). This thus gave rise to unequal discussions (leading to different interpretations) when the discussion on the structure and construction of the traditional archipelago architecture was carried out using the idiomatic technique of Western traditional building technology. With a focus on climate and earthquake which are forming factors in the building technology of the archipelago, this paper aims to express some thoughts on archipelago architectural building technology that has a difference with western building technology. Through a descriptive exploratory approach exploration is carried out with normative interpretation of the pairing of several archipelago architectural objects in the context of archipelago building technology. The exploration resulted in the discovery of archipelago building technology knowledge, namely the rationale for the construction of the two-season region, the consequences of the archipelago architectural space, the connective construction technique and the archipelago connection and the diversity of centers of gravity and the role of construction as a placemaker. This exploration is intended to form a mindset of the alignment of the local wisdom of the archipelago architecture with the science of western construction structures. There is no longer any obstacle to distrust of reasoning that the knowledge of Nusantara Architecture is indeed different from the knowledge of Western Architecture.

Keywords: Building Technology, Nusantara Architecture, Local Wisdom

\section{Pendahuluan}

Persoalan-persoalan diskusi dalam rumbang struktur dan konstruksi dalam berbagai forum selama ini umumnya ditandai dengan kemunculan perdebatan di bidang struktur dan konstruksi bangunan dengan berbagai ragam cara 
pandang. Secara khusus pembahasan terhadap struktur dan konstruksi tersebut memunculkan perbincangan hangat dalam konteks arsitektur Nusantara (konteks yang menunjuk kepada bagaimana memahami arsitektur tradisional/adat secara arsitektural bukan secara kajian budaya atau etnisitas).

Sejauh ini kaidah pembahasan tentang struktur dan konstruksi bangunan dalam aras arsitektural yang diketengahkan dalam pendidikan formal lazimnya adalah ilmu teknologi bangunan yang diturunkan dari pemikiran non-nusantara (notabene adalah teknologi bangunan arsitektur barat). Alhasil hal demikian sering memunculkan suatu diskusi yang timpang (menjurus kepada beda tafsir) ketika dilakukan tindak pembahasan struktur dan konstruksi arsitektur tradisional Nusantara dengan menggunakan idiomatika teknologi bangunan tradisional Barat.

Kebedaan geografis dimana arsitektur barat dan arsitektur nusantara berlokasi, secara logis pasti menampilkan kebedaan yang signifikan dalam upaya respon pengguna (pembangun) dalam mengadaptasi iklim dan kondisi geologis setempat. Teknologi bangunan arsitektur Nusantara yang berada pada zonasi iklim tropis lembab dan dilewati oleh jalur kegempaan Asia tak pelak mengharuskan adanya respons tanggapan olah teknologi bangunan yang arif terhadap kondisi iklim dan gejala gempa dalam berbagai varian beragam tampilan.

Sejauh ini perolehan pengetahuan teknologi bangunan arsitektural yang diajarkan pada pendidikan formal maupun informal didominasi oleh sumber pengetahuan mancanegara. Dengan demikian tak pelak aplikasi keilmuan anak bangsa dalam menegakkan bangunan arsitektur adalah aplikasi ilmu teknologi bangunan yang tanggap terhadap kondisi empat musim dan tanpa menghiraukan gempa selayaknya sumber ilmu tersebut yang bukan dari nusantara (nusantara adalah zona dua musim dan gempa sebagai batasan responsive).

Secara umum definisi struktur menurut [1] adalah susunan atau pengaturan bagian bangunan gedung yang menerima beban atau konstruksi utama dari gedung tanpa mempedulikan apakah konstruksi tersebut dapat dilihat atau tidak kelihatan. Selanjutnya dinyatakan bahwa struktur gedung umumnya terdiri atas konstruksi pondasi, dinding, kolom, plat lantai dan kuda-kuda atap. Disisi lain definisi struktur sebagai suatu entitas fisik yang memiliki sifat keseluruhan yang dapat dipahami sebagai suatu organisasi unsur-unsur pokok yang ditempatkan dalam ruang yang didalamnya karakter keseluruhan itu mendominasi interelasi bagian-bagiannya [2]. Selanjutnya muncul pertanyaan apakah cocok dan tepat definisi tersebut jika dikenakan untuk membahas arsitektur rumah Nusantara semisal rumah Jangga Dolok Toba. Senyatanya belum tentu definisi tersebut serta merta tepat sesuai disepadankan untuk menelaah system teknologi bangunan arsitektur Nusantara. Mengapa demikian? Karena jika hal ke-iklim-an dan ke-gempa-an setempat menjadi salah satu faktor pengaruh pembentukan olah ilmu teknologi bangunan setempat (local genius) maka bukankah dapat difahami jika ilmu olah teknologi bangunan nusantara pastilah 'berbeda' dengan olah ilmu teknologi bangunan mancanegara. Dengan demikian ilmu teknologi bangunan nusantara tentulah mempunyai definisi khas lokal tersendiri.

Dengan focus pada dua batasan yakni ke-iklim-an dan ke-gempa-an yang menjadi faktor pembentuk dalam teknologi penegakkan bangunan nusantara maka tulisan ini bertujuan mengungkapkan beberapa pemikiran teknologi bangunan arsitektur nusantara yang mempunyai kebedaan dengan teknologi bangunan barat. Tulisan ini dimaksudkan untuk memberikan pandangan sehingga mampu meyakinkan bahwa nusantara memiliki local genius struktur konstruksi bangunan. Dengan diketahuinya pengetahuan tersebut diharapkan tulisan ini berkontribusi terhadap pensejajaran local wisdom arsitektur nusantara dengan ilmu struktur konstruksi barat yang selama ini diajarkan di sekolah teknik Indonesia. Lebih lanjut diharapkan tidak ada lagi hambatan ketidak percayaan penalaran bahwa pengetahuan Arsitektur Nusantara memang nyata berbeda dengan pengetahuan Arsitektur Barat. Diharapkan tidak ada lagi hambatan dalam menelaah arsitektur nusantara selanjutnya karena dengan adanya pisau kaji pengetahuan nusantara yang satu demi satu terungkap oleh para peneliti melengkapi mosaic pengetahuan arsitektur.

\section{Metoda Penelitian}

Jelajah ini akan dilakukan dengan serangkaian kajian pembacaan [content analysis] atas beberapa pendapat pakar antara lain Heinz Frick dan Josef Prijotomo yang berkaitan dengan fenomena pengembangan epistemology ilmu teknologi bangunan guna memperoleh kisi-kisi adanya untuk kemudian ditelaah dengan cara kritik normative [3] sehingga dapat diklarifikasikan berbagai temuan (sebagai suatu kebedaan nusantara - barat) ilmu teknologi bangunan. Jelajah ini juga akan menyandingkan pemikiran kritis dengan memanfaatkan hasil bacaan secara content analysis [4] atas 
beberapa penelitian terkait seperti, Penelitian Gempa Bumi, Konstruksi Empyak, Struktur dan Konstruksi Arsitektur Nusantara (kasus arsitektur Jangga Dolok Toba, Statika Nusantara, Atap tanpa kuda-kuda serta Arsitektur atap [5].

Sifat jelajah ini adalah sebagai suatu penelitian eksploratif deskriptif dengan cara menampilkan telaah beberapa temuan kasus teknologi bangunan arsitektur nusantara yang akan digunakan mengokohkan adanya cara pandang mengenai struktur dan konstruksi yang berasal dari sesuai dengan karakter Arsitektur Nusantara dengan terfokus pada dua kondisi lokal yakni faktor iklim tropis dan kegempaan.

Jelajah juga akan menampilkan penyandingan dengan aplikasi olah teknologi bangunan yang menggunakan dengan cara pandang, penelitian, literatur dan makalah non-nusantara untuk memperjelas kedudukan pengetahuan teknologi bangunan yang dibangun dari pengetahuan teknologi bangunan nusantara.

\section{Pembahasan}

\subsection{Tinjauan teknologi bangunan nusantara}

Dari difinisi struktur diatas yang sudah menjadi banyak acuan dalam desain bisa dibahas digambarkan berbentuk kotak empat persegi panjang beratap datar yang otomatis tidak mengalami kendala dalam pembentukannya, karena modul bisa ditentukan ketika masih dalam taraf perancangan plan (denah/ potongan horizontal). Jika struktur berbicara tentang sistim penyaluran beban, maka konstruksi merupakan susunan dan hubungan antar bahan bangunan bahan bangunan sedemikian rupa sehingga penyusunan tersebut menjadi satu kesatuan yang dapat menahan beban dan menjadi kuat [6]

Namun bila konsep demikian diterapkan dalam sistim struktur dan konstruksi rumah Nusantara maka akan mengalami kendala dalam pembentukannya. secara umum mengingat terdapat sekitar sekitar enam ratus jenis bangunan arsitektur nusantara beratap lancip miring keatas. Kendala yang dihadap dalam pembentukan struktur dan konstruksi bila menggunakan difinisi secara umum yang lazim diketahui, maka akan mengalami kesulitan proses pembentukannya. Struktur dan konstruksi bangunan Nusantara memiliki keunikan dalam pembentukan strukturnya yakni focus pada pembentukan atap dengan segala kerumitan dan sistim konstruksinya yang bekerja secara saling terkoneksi.

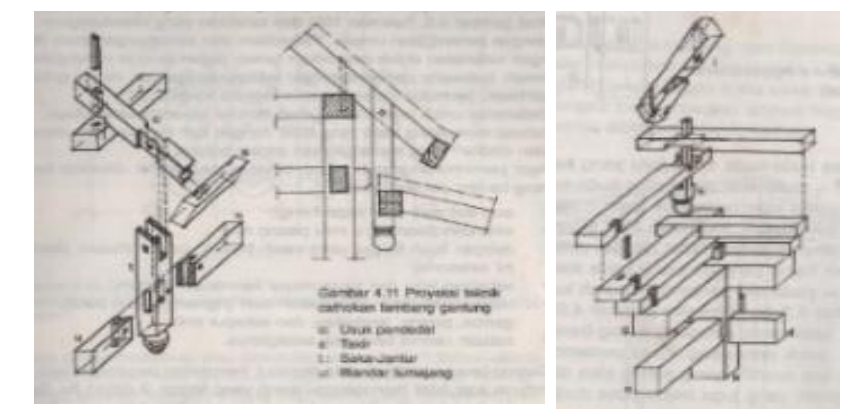

Gambar 1: Keragaman sistim sambungan konstruksi kayu di Indonesia

\subsection{Pengetahuan struktur-konstruksi nusantara}

Pembahasan dimulai dengan analisis arsitektural atas bangunan arsitektur nusantara diselaraskan dengan faktor yang terkait dengan pembentukan sistem struktur dan konstruksi, yakni iklim dan gempa bumi. Secara umum bangunan arsitektur bila diperhitungkan terhadap iklim (dimana manusia sebagai penghuni arsitektur membina bangunan untuk bernaung) maka dibutuhkan karakter penaung dalam bentuk konstruksi yang berdimensi luas dibagian atas sebagai bentuk penaung membentuk bayangan (shading) bagian bawahnya. Dapat difahami kemudian mengapa bentukan atap arsitektur nusantara demikian dominan besar dan megah

Sedangkan bangunan arsitektur nusantara yang digunakan manusia sebagai upaya perlindungan memperoleh keamanan terhadap gempa bumi disusun dengan teknologi perkuatan pada struktur utama dan menggubah teknologi tumpuan dengan meletakkan pondasi bukan menanam pondasi sehingga tumpuan menjadi mudah bergoyang seirama 
gempa yang mungkin melanda. Dapat difahami kemudian bahwa letak kolom atau dudukan struktur tegak arsitektur nusantara didominasi oleh system umpak dan ceblokan menjamin ke'goyang'an penumpu tersebut. Suatu keunikan olah kriya fenomena teknologi bangunan yang mempunyai kebedaan dengan pengetahuan teknologi bangunan selainnusantara yang difahami hingga kini.

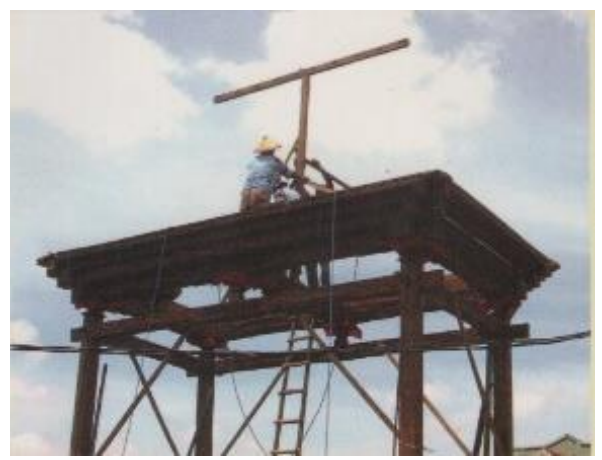

Gambar 2. Sistim rancangan struktur menggunakan kekuatan dan kekakuan pada badan bangunan

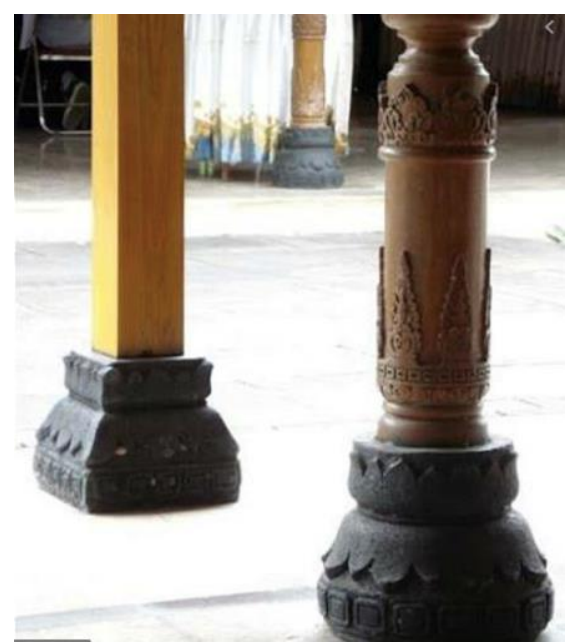

Gambar 3. Kekakuan di pusat konstruksi (struktur soko guru) terbukti berdaya baik mengantisipasi gempa bumi

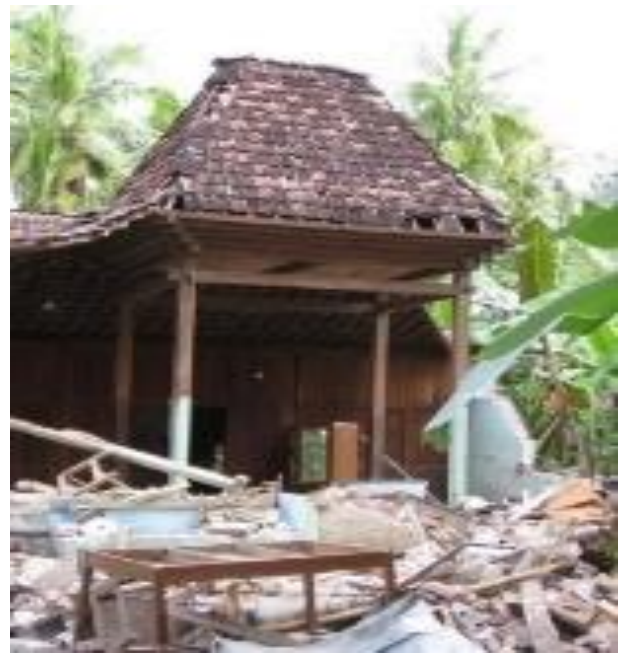

Gambar 4. Sistem peletakan kolom dengan cara 'letak’ umpak menjamin goyangan struktur vertical 
Pada bangunan arsitektur nusantara terdapat struktur pengaku yang berupa lempeng rangkaian konstruksi kayu/bamboo yang dimanfaatkan sebagai pengaku bidang atap. Teknologi demikian merupakan respons terhadap kebutuhan akan teduhan / naungan yang lebar juga merupakan jawaban atas kondisi gempa mengingat struktur demikian akan sangat ringan dan terangkai sebagai suatu kesatuan yang saling mengikat tidak akan terburai ketika gempa melanda. Keterburaian bahan bangunan adalah hal yang dikuatirkan oleh manusia yang berdiam dibawah struktur bangunan dimana runtuhan bahan bangunan justru yang mencelakakan manusia di saat gempa.

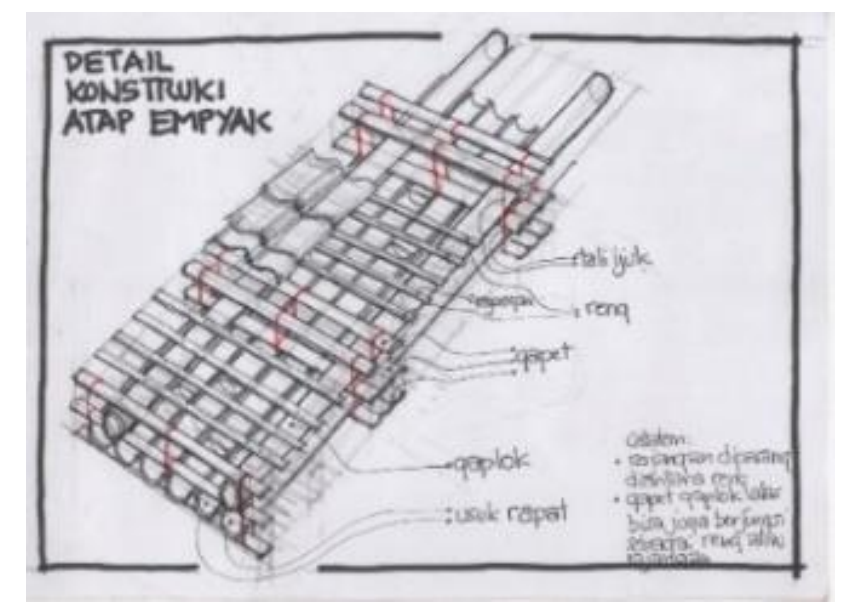

Gambar 5. Sistim perkuatan pada lempeng atap empyak merangkai bahan bangunan

\subsection{Pengetahuan ruang arsitektur nusantara}

Ruang yang dipahami selama ini merupakan entitas dimensi yang terbentuk oleh adanya pembatas antara ruang luar dan ruang dalam ataupun pembatasan antar ruang dalam itu sendir. Alhasil ruang dalam berbatas secara kubikal (lantai, dinding, atap) yang menyebabkan keterpisahan dari ruang luar. Teknik pembentukan ruang dalam dengan metode pembatasan ruang demikian dipengaruhi oleh karakter kehidupan dalam rangka membangun perlindungan terhadap buruknya cuaca iklim (di belahan barat bahkan sampai 4 jenis musim yang harus diantisipasi).

Pembentukan ruang arsitektur selama ini didasarkan pada pemenuhan kebutuhan ruang yang diatur dalam sebuah peraturan bangunan [7]. Peraturan bangunan demikian dilandasi pemikiran ruang untuk memberi kesempatan penuh bagi manusia untuk hidup di dalam ruang. Dengan adanya landasan piker demikian maka terlihat sehingga bahwa bentukan arsitektur yang dihasilkan berupa tatanan ruang berbilik-bilik (banyak dinding batas didalam bangunan). Pembiikan demikian adalah merupakan respons terhadap kondisi iklim dan alam yang kurang nyaman untuk hidup diluar bangunan. Peranan dinding bilik dengan demikian menjadi dominan yang berlaku sebagai batas dinding proteksi terhadap gangguan alam dan sebagai bidang rambat panas sari luar hingga bisa menghangatkan ruangan.
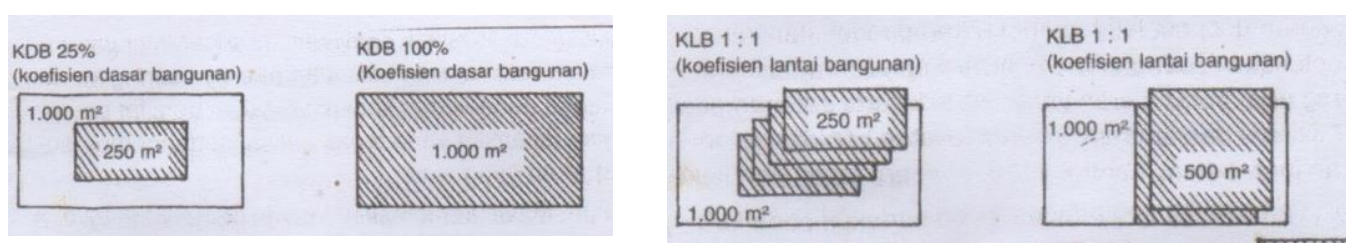

Gambar 6. Peraturan bangunan Indonesia yang mengadopsi pemahamanpembilikan arsitektur non-nusantara. 
Telaah teori sistem ruang yang mengacu pada kebutuhan ruang arsitektur nusantara menunjukkan kebedaan pemahaman. Sebagian besar arsitektur tradisional di Indonesia menunjukkan varian tatanan pembilikan dengan type tata denah bersama (open plan) mengakomodasi kegiatan harian penghuni dalam kekhasan kehidupan manusia nusantara dalam hubungan yang berkerabat, berkomunitas, dalam menyelenggarakan rangkaian ritual. Selain itu kondisi iklim dimana angin berhembus bertiup secara perlahan tidak menakutkan dan mengkuatirkan bahkan menjadika kesejukan yang suitable / pas belaka. Tidak mengherankan jika kemudian tatanan ruang dalam nusantara selain nir-dinding sekat (open plan) maka pelingkup pembatas ruang luar dan ruang dalam dirancang bukan sebagai pembatas massif namun dibuat bernafas me-leluasa-kan hembusan angin mengalir keseluruh ruangan. Pembatas ruang pun bukan ditempatkan sebagai sarana proteksi terhadap iklim namun sebagai sarana penghubung luar dalam dan ruang yang harmonis menyatukam manusia dengan lingkungan alamnya.

Konsep tatanan ruang nusantara demikian memberi jaminan penghuni tidak terkena limpasan hujan dan terik panas matahari serta jaminan pergerakan angin bisa leluasa keluar masuk ruang. Baik penaung atau peneduh adalah tindakan menempatkan diri dibawah sebuah penaung, tindakan ini bukanlah untuk menyembunyikan diri atau menyelamatkan diri tapi sepenuhnya adalah tindakan untuk tidak secara langsung diterpa derasnya hujan dan teriknya matahari [8]. Tindakan ini seseorang tidak terpisahkan atau terisolasi dari lingkungan sekitarnya, itu berarti perasaan bersatu dengan lingkungannya masih dapat diperoleh.

Ruang yang terbentuk oleh pelingkup lantai, dinding dan atap pada arsitektur nusantara menunjukkan bahwa letak dari empyak/payon yang ditata pada ketinggian tertentu dari muka lantai menghasilkan volume ruang bagi terselenggaranya kegiatan. Hal demikian menunjukkan bahwa selain elemen lantai yang membentuk volume ruangan secara horisontal maka atap melengkapkannya sebagai elemen pembentuk volume ruangan secara vertikal.

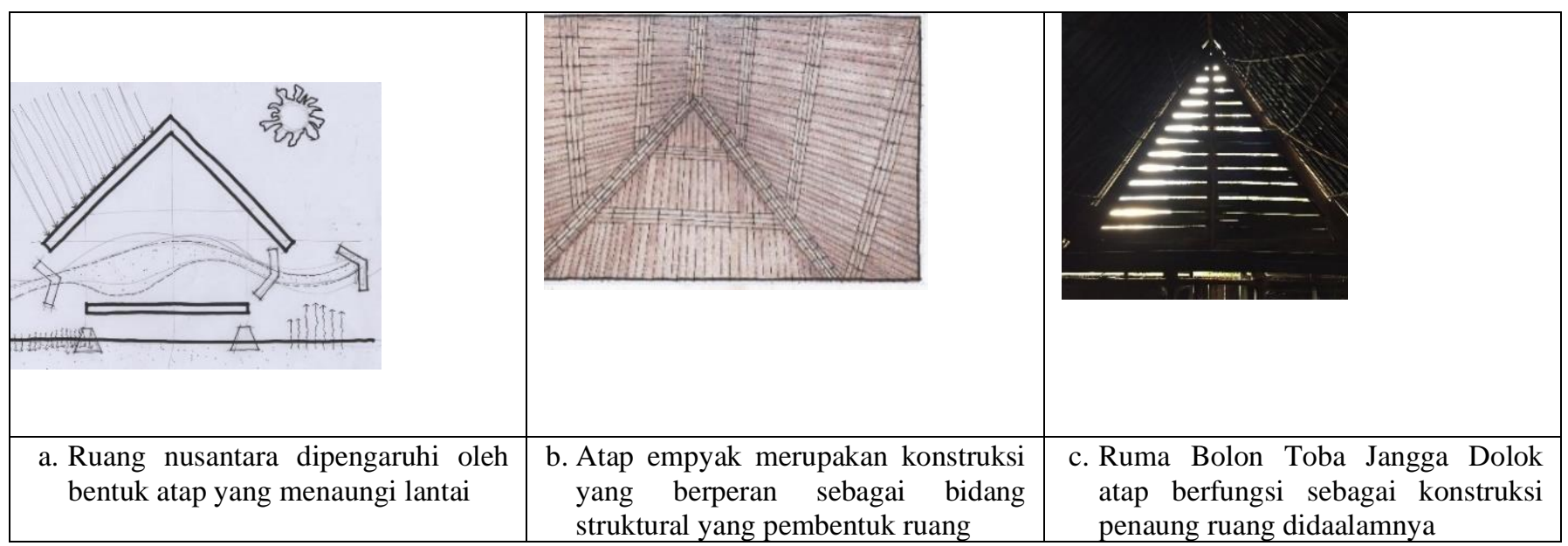

Gambar 7 : Peran atap sebagai pembentuk ruang arsitektur nusantara

Arsitektur nusantara dalam menyikapi iklim panas tropis terik matahari sepanjang hari mengarahkan kepada adanya respons manusi berupa tindakan tektonika dalam menyikapi cuaca tersebut. Kepedulian dan kepentingan antisipasi yang tinggi terhadap terpaan sinar matahari mewujudkan tindakan serius dalam mengolah penaung tempat bermukim. Tidak mengherankan jika keseriusan tersebut melairkan bentukan yang demikian beragam dan bercitra artistik. Atap lebar yang fungsioanl sebagai penaung juga menyediakan kesempatan bagi perwujudan cita rasa seni penghuninya berupa ornamentasi sarat makna. Kondisi hujan tropic juga menjadikan manusia harus bersikap serius mengantisipasinya demi kenyamanan hidup. Tak pelak pilihan atap miring terjal menjadi solusi logis mengalirkan deras air hujan. Sungguh suatu tndakan teknologis yang sangat tanggap lingkungan alam. 


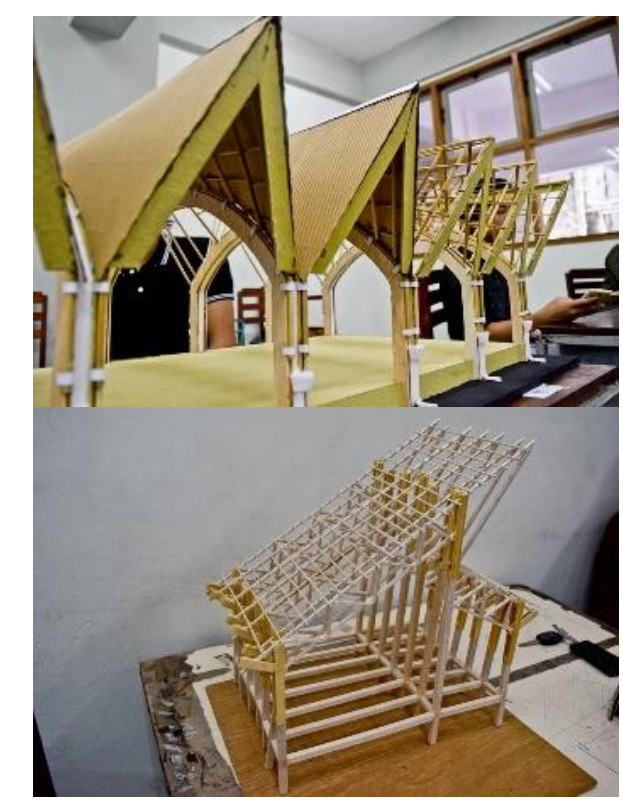

Gambar 8: Konstruksi atap di wilayah ber dua musim dengan ciri kemiringan yang terjal

\subsection{Mengungkap kearifan lokal teknologi bangunan arsitektur nusantara}

Dilandasi pemahaman bahwa akibat dari lokalitas dimana arsitektur ditempatkan yang mempengaruhi daya antisipasi manusia nusantara yang terwujud dalam olahan tektonika arsitektur nusantara dengan kekhasan/kearifan lokal maka arsitektur nusantara boleh jadi merupakan khasanah pengetahuan indigenous yang tidak dapat diremehkan kehandalannya bagi pengetahuan teknologi bangunan.

Di bawah disampaikan beberapa telaah spekulatif sebagai narasi pembuka wacana bagi jelajah eksplorasi upaya uncovering pengetahuan struktur dan konstruksi yang berbasis pengetahuan nusantara. Beberapa kajian spekulatif tersebut diantaranya dengan Teknik eksplanasi, Teknik pembandingan dan logika Teknik dengan subyek arsitektur nusantara.[9].

Beberapa dugaan awal banyak diajukan bahwa sistim struktur bangunan jenis bangunan di nusantara berbentuk tiga dimensi dan merupakan struktur yang di didirikan bisa menanggulangi masalah gempa bumi. Memang selayaknya struktur dan konstruksi bangunan sangat erat hubungannya dengan pengaruh gempa bumi karena kinerja struktur sangat sangat membantu agar bangunan tetap berdiri dan bergerak sesuai dengan pergerakan gempa bumi. Di bawah ini disampaikan telaah praktis beberapa interpretasi sederhana tentang kaitan pembentukan tektonika nusantara yang berkaitan dengan respons antisipatif terhadap ancaman gempa bumi. Pengetahuan teknologi bangunan di arsitektur nusantara dominan menggunakan teknik ikat dan pelubangan (lubang-tancap) dalam menyambung rangkaikan bahan bangunan. Teknik ikat dari bahan organic memiliki keuntungan konstruksi yang memungkinkan bahan tidak saling lengket kaku melainkan berpotensi (sedikit) bergerak yang memang dibutuhkan oleh kerangka bangunan untuk mengantisipasi apabila ada angina deras ataupun gempa bumi. Konstruksi bangunan akan sedikit bergerak mengayun hingga tidak menimbulkan kepatahan atau kegeseran frontal. Yang menarik adalah teknik rangkaian ikatan temali yang demikian beragam dan sangat artistik rapi dalam pengerjaannya (adanya pola, ritme yang rapih sehinggaberkesan dekoratif). Salah satu hal yang menjadi fokus pengetahuan konstruksi adalah persambuang atau persendian. Teknik konstruksi nusantara menyajikan tumpukan dan sambungan yang unik. Sambungan yang digunakan pada konstruksi kayu karena keterbatasan teknologi alat menjadikan sambungan berupa lubang dengan tancap yang tidak ketat benar. Justru ketidak ketatan yang wajar inilah menjadikan konstruksi sambungan yang memungkinkan ayunan menanggapi gaya gempa yang mungkin datang. Bahkan untuk memperoleh adanya kondisi tidak ketat beberapa menggunakan lapis kain berwarna untuk mencegah lengketnya sambungan karena getah kayu. 


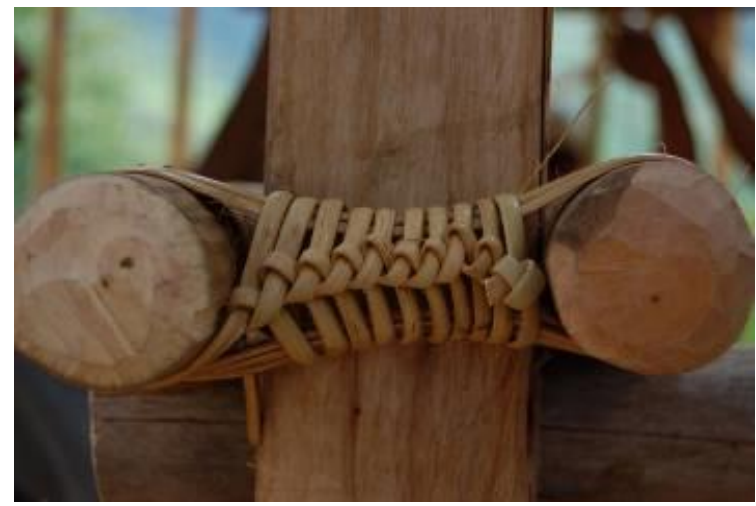

Gambar 9. Teknik konstruksi ikat dari rotan akan kencang saat rotan mengering

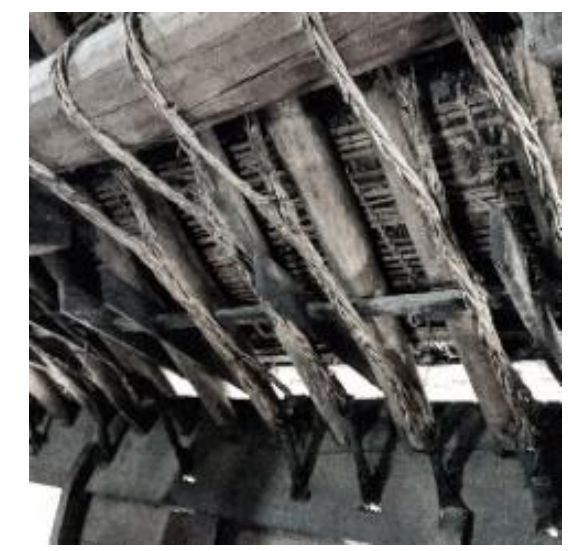

Gambar 10. Tali rotan masih ada toleransi bergerak saat terjadi gempa bumi

Teknik tumpukan batang juga menjadi Teknik yang dominan di nusantara utamanya banyak di temukan di nusantara timur dengan pengecualian terdapat juga di nusantara bahagian barat (simalungun, toba, karo misalnya). Konstruksi teknik tumpukan kayu demikian secara struktural memungkinkan adanya gerakan dan tidak lengket kaku sebagai suatu kondisi rangkaian yang memang bisa diandalkan untuk menyikapi gempa.

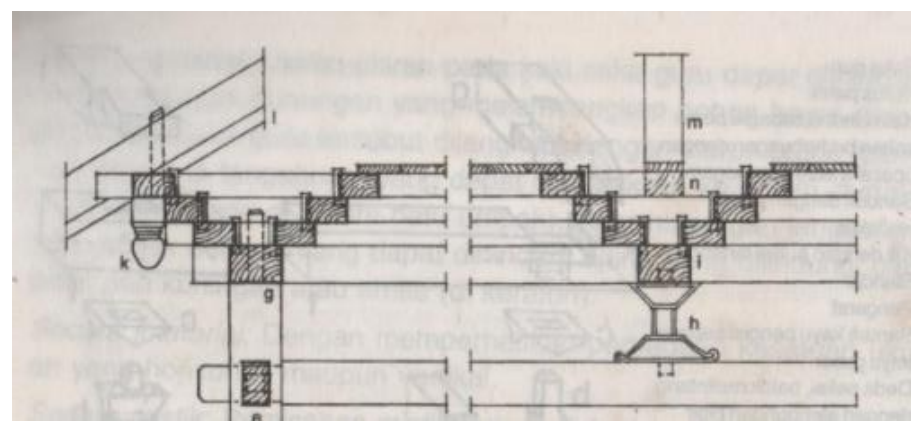

Gambar 11 : Model konstruksi tumpeng sari selain berfungsi sebagai unsur utama kekuatan, juga sebagai bantalan bergerak saat terjadi gempa bum

Mencermati bentukan konstruksi bangunan nusantara dengan cara penjajaran atau komparatif dengan konteks amatan struktur konstruksi ternyata menampilkan keunikan tersendiri dimana bangunan tersebut ternyata memiliki atau dibengun dengan model peletakan titik gaya berat yang cukup beragam. Setidaknya jelajah ini memperoleh tiga system struktur yaitu bangunan dengan titik berat kekuatan pada tengah bangunan dengan andalan kekuatan pada 'tumpangsari' (arsitektur Jawa), bangunan dengan lantai dan tiang sebagai andalan kekuatan struktural, bangunan dengan lantai sebagai andalan kekuatan structural. Dengan demikian faktor pembentuk rangkaian konstruksi pembentuk struktur bangunan nusantara tidak hanya semata sebagai pengokoh bangunan namun diberikan peluang berfungsi juga sebagai penanda tempat (place) ataupun tempat (place) itu sendiri. 


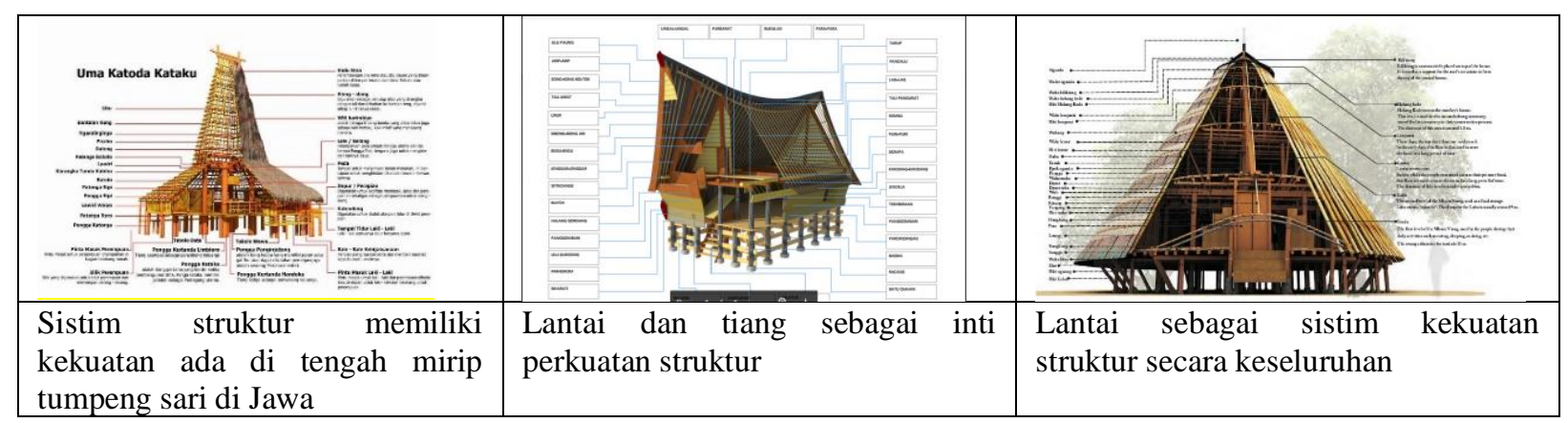

Gambar 12 : Beberapa peletakan titik kekuatan struktur arsitektur nusantara

Jelajah ini meruakan langkah awal sederhana dalam upaya menggali kearifan lokal arsitektur nusantara dalam konteks teknologi bangunan yang diyakini merupakan konteks yang tepat sebagai suatu telaah dalam ranah ilmu arsitektur (melengkapi pengetahuan yang sejauh ini telah banyak dilakukan atas obyek bangunan tradisional nusantara dengan sudut pandang ranah antropologis ataupun etnografis).

Sebagai suatu jelajah sederhana maka tulisan ini tentu saja belum mencapai suatu generalisasi namun setidaknya metoda dan penalaran yang diperoleh dari rangkaian jelajah ini menimbulkan danya pemikiran baru yang memberikan keyakinan dan pembuktian empirical bahwa teknologi bangunan di wilayah dua musim (nusantara) mempunyai kebedaan signifikan dengan teknologi bangunan di wilayah empat musim. Dengan demikian selayaknya tidak perlu dipertanyakan hal relevansi pengajaran pengetahuan yang selama ini dlberikan di sekolah Teknik Indonesia yang kebanyakan mengacu pengetahuan teknologi bangunan untuk wilayah empat musim namun akan lebih bijaksana jika pengetahuan konstruksi bangunan indonesia dilengkapkan dengan upaya keras penggalian penjelajahan pengungkapan segenap pengetahuan teknologi bangunan nusantara yang memang berakar sumber dari wilayah dua musim.

Tantangan tersebut diatas tentu saja tidak semudah membalik telapak tangan, terbukti puluhan tahun dominasi pengajaran teknologi bangunan masih didominasi oleh pengetahuan struktur konstruksi dari/bagi bangunan di wilayah empat musim. Adapun Teknik analisis perhitungan teknologi bangunan di Indonesia juga masih berkutat pada pemahaman structural dua dimensional dimana dengan kemajuan teknologi sebenarnya sudah dapat dijangkau pengetahuan statika tiga dimensional yang berkemungkinan sebagai alat jelajah bagi pengungkapan pengetahuan arsitektur nusantara lebih intensif.

\section{Kesimpulan}

Arsitektur, struktur dan konstruksi nusantara merupakan satu kesatuan wujud desain yang menyatu dengan lingkungan, kawasan geografi Indonesia. Jika ingin memahami arsitektur nusantara tersebut maka diperlukan pemahaman secara menyeluruh hakekat karya arsitektur tersebut. Jika masih banyak menggunakan teori-teori dari mancanegara maka akan kesulitan untuk masuk kedalam pemahaman yang sebenarnya. Hambatan ini dikarenakan adanya perbedaan prinsip kaidah-kaidah struktur dan konstruksi antara yang dari mancanegara dengan teori lokal. Dibutuhkan penguatan terhadap teori lokal untuk membedah arsitektur, struktur dan konstruksi nusantara. Lebih banyak membaca dan memahami teori konstruksi nusantara yang didalamnya memuat keunikan arsitektur di Indonesia. Dibutuhkan langkah membangun teori lokal yang banyak lagi untuk mengungkap dan membedah arsitektur, struktur dan konstruksi nusantara dengan cara banyak penelitian yang mengangkat arsitektur lokal. Tulisan diatas melengkapkan pernyataan kesimpulan dengan contoh-contoh temuan pengetahuan teknologi bangunan nusantara yaitu dasar pemikiran struktur konstruksi wilayah dua musim, konsekwensi ruang arsitektural nusantara, teknik konstruksi ikat dan sambungan nusantara dan keragaman titik berat serta peran konstruksi sebagai pembentuk tempat (place). Semoga tulisan dangkal ini menjadikan pemicu bagi penelitian pengungkapan pengetahuan teknologi bangunan nusantara selanjutnya secara lebih intensif. 


\section{Referensi}

[1] Frick, Heinz. dkk (2007) Sistem bentuk struktur bangunan. Kanisius \& Soegijapranata University Press, Semarang

[2] Schodek, Daniel L.(1999) Struktur (terjemahan). Erlangga Press, Jakarta

[3] Attoe, W (1978). Architecture and critical Imagination, John Wiley \& Sons, New York

[4] Zuchdi, D, dkk (2019), Analisis Konten, Etnografi\&Grounded Theory, dan Hermenutika dalam Penelitian, Bumi Aksara, Jakarta

[5] Koesmartadi, Ch. (2019) Bernaung di Bawah Bayang-bayang Atap. Universitas Katolik Soegijapranata. Semarang

[6] Frick, Heinz. dkk (2001) Ilmu konstruksi struktur bangunan. Kanisius \& Soegijapranata University Press. Semarang

[7] Zahnd, Markus (1999) perancangan kota terpadu. Kanisius \& Soegijapranata University Press.

[8] Prijotomo, Josef (2018), Prijotomo membenahi Arsitektur Nusantara, PT Wastu Lanas Grafika, Surabaya

[9] Koesmartadi, Ch. (2019) Bernaung di Bawah Bayang-bayang Atap. Universitas Katolik Soegijapranata. Semarang

[10] Prijotomo, Josef (2019) Omo Uma Ume Omah - Jelajah Arsitektur Nusantara yang Belum Usai. PT Wastu Lanas Grafika, Surabaya 


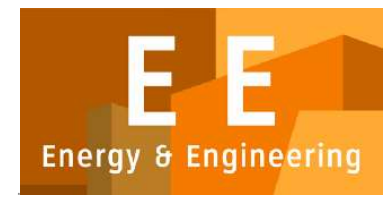

PAPER - OPEN ACCESS

\title{
Jelajah Kearifan Teknologi Bangunan Arsitektur Nusantara
}

\author{
Author $\quad:$ Ch. Koesmartadi dan D.Lindarto \\ DOI $\quad: 10.32734 /$ ee.v3i1.851 \\ Electronic ISSN $\quad: 2654-704 X$ \\ Print ISSN : $2654-7031$
}

Volume 3 Issue 1 - 2020 TALENTA Conference Series: Energy \& Engineering (EE)

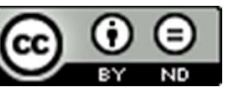

This work is licensed under a Creative Commons Attribution-NoDerivatives 4.0 International License.

Published under licence by TALENTA Publisher, Universitas Sumatera Utara

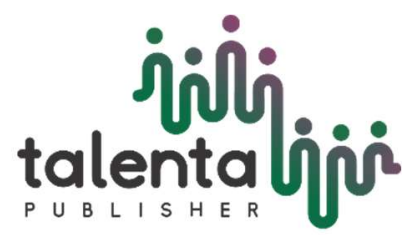

